\title{
A PESQUISA EM TERRENOS BALDIOS: arte, vida, conhecimento, crianças e crônicas
}

Carlos Roberto de Carvalho

Universidade Federal Rural do Rio de Janeiro - UFRRJ, Brasil

Flávia Miller Naethe Motta

Universidade Federal Rural do Rio de Janeiro - UFRRJ, Brasil

Patrícia Kersch Pedrosa Bento

Universidade Federal Rural do Rio de Janeiro - PPGEduc/UFRRJ, Brasil

\begin{abstract}
Resumo
$\mathrm{O}$ artigo em questão busca estabelecer uma relação entre filosofia e literatura para, em defesa da heterociência - que combina os elementos arquitetônicos e metodológicos comuns a ambos - como um projeto, responder ao que é a pesquisa em Ciências Humanas. A discussão chega à produção de uma mestranda; "Patrícia", que narrando aproxima-se das crianças que pesquisa e nos aproxima delas. Ao escrever as crônicas que compuseram a dissertação, a pesquisadora construiu uma autobiografia. Falou de si e do outro, foi impactada e sofreu o efeito constitutivo dos encontros. Ao organizar, no texto escrito, as vivências da professora, o fez numa perspectiva estética, descrevendo uma vivência ética. A dissertação, pensada na perspectiva de uma ciência outra, "alargou" o gênero acadêmico, aproximando-o das crônicas, construindo o rigor heterocientífico com o qual consideramos ter podido "pensar sem corrimões" produzindo um saber que tal como a cultura permite espalhar/espelhar, arte, vida e conhecimento.
\end{abstract}

Palavras-chave: Heterociência; Gênero; Estética; Pesquisa com crianças.

\begin{abstract}
This paper intends to criate a relationship between philosophy and literature to, in defense of heteroscience - which combines the architechtonic and methodological elements common to both as a project, to answer what is research in Human Sciences. The discussion leads to the the production of a Master's student; "Patricia", who gets closer to the children that she researches through narration and also gets us closer to them. The researcher built an autobiography by writing the chronicles that composed the dissertation. She spoke of yourself and the other, was impacted and suffered the constitutive effect of the meetings. By organizing, in the written text, the experiences of the teacher, she did so from an aesthetic perspective, describing an ethical experience. The dissertation aims to "enlarge" the academic genre, making it closer to the chronicles, ensuring the "heteroscientific" rigor, with which we intend to "think without a banister", and producing a knowledge that, just like culture, spreads/reflecs art, life and knowledge.
\end{abstract}

Keywords: Heteroscience; Genre; Aesthetics; Research with child. 


\section{Introdução}

To be, or not to be, that is the question.

Hamlet, Act III, Scene-1

As palavras de Hamlet nos levam ao encontro de velhos filósofos da antiga Grécia. Encontro sempre marcado, como nos diria Benjamin (2005), com todos aqueles que nos precederam e que clamam pelas promessas ainda não cumpridas. As palavras de Hamlet, paridas na angústia do ser, ou não ser, foram ditas bem antes de Shakespeare escrevê-las: nasceram no alvorecer da civilização ocidental. Por isso, é pra lá que nos encaminhamos ao encontro de Platão, de Aristóteles, de Heráclito e de Parmênides, ao encontro de todos os grandes! "Quando fala um dos grandes que só uma vez aparecem, os pequenos devem calarse" - aconselha-nos Kappus (2001, p.19). As palavras do bardo e do jovem poeta de Rilke convidam-nos à ausculta sensível do Ser no seu vir-a-ser necessário; convida-nos ao silêncio, a penetrar "surdamente no reino das palavras". Ouçamos, então, esses velhos senhores no tempo em que se discutia a questão do sentido do ser. Ser ou não-Ser, era a questão!

Em meio a este debate vital, Aristóteles (1979) escreveu uma obra magnifica: Ética a Nicômaco. Nesta obra, discordou de seu mestre que acreditava na perfeição incorruptível da ideia e no fato de o mundo material ser somente a sombra do ser, cópia imperfeita da ideia perfeita e eterna. Aristóteles, ao contrário, achava que esta ideia não era uma boa ideia; então, pensou a contrapelo: essa ideia de dois mundos, um aqui e outro lá, é uma ilusão da razão. Para Aristóteles, o dualismo platônico não tinha sentido algum. Diante daquilo, ele percebia como sendo o mundo.

O afresco "Escola de Atenas"1, pintado por Rafael Sânzio, sintetiza de forma plástica esse diálogo entre o discípulo e o mestre. Rafael apresenta o cerne dessa questão travada há séculos. No centro da cena pintada por Rafael, estão Platão e Aristóteles ladeados por outros importantes filósofos do mundo antigo. Platão está com o indicador apontado para o alto, e Aristóteles, com a mão direita espalmada para baixo, carregando na outra mão um grande livro: Ética a Nicômaco. São gestos bastante significativos. O dedo indicador de Platão apontado para alto representa a filosofia abstrata e teórica, enquanto a mão de Aristóteles, espalmada para baixo, representa a filosofia natural e empírica. Com estes dois gestos, o pintor nos mostra de modo artístico duas concepções teóricas sobre o Ser. Se Platão via o Ser como uma ideia, Aristóteles não via este do mesmo modo; via diferente. O cosmos era tudo o que existia fisicamente, era a soma do espaço e do tempo, assim como a soma das mais variadas formas de matéria, como planetas, estrelas, galáxias, flores, borboletas, sorvetes, tartarugas, livros, artigos, copos, taças, mesas, cadeiras e jujubas. Não via o mundo como sombra da ideia, mas a encarnação desta na matéria, unindo, destarte, o céu a terra, o sensível ao inteligível, o homem à divindade.

Para Aristóteles, o mundo era a própria realidade se manifestando em ato e potência. Ato-potência-ato, bailando eternamente no grande teatro da natureza, gerando todas as coisas visíveis e invisíveis. Semente-árvore-flor-fruto-semente-mundo. Ser-no-mundo-com-omundo, no movimento ininterrupto da semente ao fruto, do fruto à semente, sem intervalos. 
Para Aristóteles, o mundo não estava no além estava no mundo, onde as coisas estão e aparecem no seu aqui-agora como o fluir das águas de um rio em plena luz do sol. Não existia outro mundo; somente este dado aos sentidos, um só mundo, uma só substância: Água-Terra-Fogo-Vento! Tudo tinha matéria e forma. Matéria e forma eram a essência de todas as coisas que havia. Diante dessa evidência indubitável, Aristóteles com a mão direita espalmada para baixo sentencia: O SER SE DIZ POR VÁRIOS MODOS.

O pensamento de Aristóteles partiu de duas teses contrárias: uma defendida por Parmênides e outra defendida por Heráclito. Para o primeiro, a coisa é, e não podia deixar de ser. Não mudava nunca: o que é, é. Para o segundo, a coisa não é porque, na natureza, tudo flui e, portanto, não se podia "banhar-se duas vezes na mesma água de um rio". Nem um nem outro estava absolutamente certo ou errado, apenas ocupavam posições extremas, faltava um meio termo, pois tanto um como outro tinham, sim, alguma razão, mas que não correspondia à verdade do Ser. Aristóteles via o mundo material que mudava, mas que também permanecia em sua identidade, algo que se atualizava no seu próprio movimento. Diante dessa questão pensou dialeticamente: tese-antítese-síntese: $O \operatorname{Ser} E$, $O$ Ser $N \tilde{A} O-E$. Logo se diz de vários modos, no movimento próprio do seu próprio vir-a-ser, naquilo que se É-SENDO na unidade de seu movimento de potência-ato.

Mas por que estamos contando essa história? Por que Heráclito, Parmênides, Aristóteles e Hamlet? O que esta discussão tem a ver com a nossa pesquisa? Resposta: Tudo! Porque tudo tem a ver com a pergunta: O que é o Ser?

\section{Questão de gênero}

É em torno a essa questão que encontramos o busílis de nosso pensamento a respeito da natureza dos textos, textos que nos aparecem de formas variadas. Frente à miríade do dizer humano, temos nos perguntado: qual dentre estes gêneros será o mais capaz de nos desvelar a verdade mais verdadeira sobre os seres humanos, dando-nos à sua última palavra? Ainda não encontramos resposta que nos satisfaça nem na ciência nem na filosofia, por enquanto a questão permanece em aberto. É essa questão em aberto que nos faz pensar sobre os textos acadêmicos em confronto com outros gêneros de textos; é essa questão que nos faz pensar sobre o que é ciência.

A ciência, sobre a qual nos perguntamos, é a Ciência Moderna, a ciência do cálculo e da razão, do "Penso, logo existo"2, que estuda os entes, mas não o sentido do ser. Um tipo de conhecimento que se autodefine como especializado, que tem um corpo de conhecimentos sistematizados, adquirido via observação, identificação, pesquisa e explicação de determinadas categorias de fenômenos e fatos, e formulados metódica e racionalmente.

Mas também não poderíamos definir a arte com esses mesmos termos? Arte também não seria um tipo de conhecimento que possui um corpo de conhecimentos sistematizados, adquirido, portanto, pela observação, identificação, pesquisa, informação e explicação de determinadas categorias de fenômenos e fatos, assim como formulados metódica e racionalmente, tendo em vista a realização de algo? Que arte, tal qual a ciência, não é também 
conhecimento especializado e sistemático? Os conhecimentos artísticos, embora diferentes dos produzidos pelas ciências, não partem também das mesmas exigências? Então qual é a diferença?

Respondemos: as ciências estudam os entes e suas leis universais, com procedimentos técnicos e metodológicos aplicáveis a todos os seres, como se TODOS fossem UM ou como se $U M$ fosse TODOS, enquanto as artes estudam o sentido do ser, os sentidos da existência, a contingência de seu Ser-Aparecer. Diferentemente das ciências da natureza, a arte trabalha com procedimentos e técnicas, métodos particulares, contingentes, autorais, não raro únicos e irrepetíveis. A arte não é generalizável, vê cada indivíduo como um indivíduo único: Este indivíduo!; Aquele indivíduo!; Outro indivíduo! Embora únicos e distintos entre si, em todos se manifesta a essência humana, todavia, devido à sua indeterminação, não podem ser tomados como exemplares de sua espécie. É parte da espécie, mas não a representa, pois cada um é cada um, não pode representar o todo. Como tal, só podemos contemplá-lo, e nunca estudá-lo como um ente somente, mas como um ser expressivo em seu devir. Neste sentido, tal como Shakespeare, vemos o homem como obra de si próprio, de suas circunstâncias. Diznos sobre ele, mais uma vez, Hamlet.

Que obra de arte é o homem: tão nobre no raciocínio, tão vário na capacidade; em forma e movimento, tão preciso e admirável; na ação é como um anjo; no entendimento é como um Deus; a beleza do mundo, o exemplo dos animais (Ato II, Cena 2)

Mas, no nosso perguntar, não é pela distinção entre arte e ciência que estamos interessados, mas pela sua definição excludente que arroga para si o primado da verdade sobre o ser dos entes, relegando, assim, outras racionalidades ao degredo. Tal pensamento acabou por identificar os conhecimentos produzidos pelas ciências como sendo os mais verdadeiros e seguros em detrimento das outras esferas do conhecimento.

Não negamos, por exemplo, as verdades da ciência Newtoniana. É verdade que a lei da gravidade atua em todos os corpos e, dessa forma, se percebe sua facticidade. Todavia, contra essa posição das ciências da natureza frente às outras formas de conhecimentos, poder-se-ia alegar a própria história das descobertas científicas que, ao longo do tempo, foi sendo reformulada, confirmada ou falseada, indicando-nos, assim, que nem sempre, apesar do rigor de suas práticas, se provaram verdadeiras e que, portanto, nem sempre dizem a verdade pensando dizê-las.

Certezas e enganos são o movimento de tais ciências e também a razão de seus progressos. A história das ciências é muito instrutiva: ela nos ensina que são os erros, e não as certezas absolutas, que fazem o progresso das ciências em geral e que o conhecimento sobre algo é sempre provisório, porque diz-nos Hamlet: "Há mais coisas entre o céu e a terra do que sonha nossa vã filosofia" (Ato I, Cena 5).

Concordamos com Newton que nos faz sentir a força gravitacional a partir do simples tombar de um fruto sobre a terra, mas também concordamos com Drummond (1985, p.78) quando nos diz que os "Meus ombros Suportam o Mundo": "Teus ombros suportam o mundo, 
e ele não pesa mais que a mão de uma criança". Tanto Drummond (poeta) quanto Newton (físico) nos fazem meditar sobre o peso do mundo sobre nossos ombros. Neste sentido, quem diz mais sobre o peso de nossa condição humana: Kant, Shakespeare, Nietzsche, Dostoievski, Cervantes, Freud, Marx, Goethe, ou Newton? Não temos resposta conclusiva; temos só a dúvida que nos inquieta...

No silêncio da espera paciente e serena pelo inesperado da resposta, temos nos perguntado ainda: por que não podemos lançar mão de outros gêneros para se pensar o sentido da existência humana cuja essência é a sua própria existência livre e indeterminada? Tais indagações têm nos feito pensar sobre os conceitos que repetimos ad infitum, sem ponderar sobre sua potencialidade infinita de dizer tanto na ciência, como na arte e como na vida. Temos nos esforçado pensar cada palavra como se a ouvíssemos cada vez pela primeira vez no movimento essencial de sua enunciação. Assim mesmo como Drummond nos ensina em a "Procura da Poesia".

[...] Penetra surdamente no reino das palavras/Lá estão os poemas que esperam ser escritos/Estão paralisados, mas não há desespero, há calma e frescura na superfície intata. Ei-los sós e mudos, em estado de dicionário. Convive com teus poemas, antes de escrevê-los. Tem paciência se obscuros. Calma, se te provocam. Espera que cada um se realize e consume com seu poder de palavra. (2012, p.11)

O poema de Drummond é o nosso Vade Mecum. Seus versos dizem tudo ou quase tudo sobre o que estamos querendo dizer a respeito da liturgia da palavra científica, poética e viva. Palavra que nunca pode ser um mero repetir, mas pensada nas possibilidades do ser-vir-aser-dizer no contexto que antecede o ato de todo dizer. Os versos do poeta esclarecem-nos ainda sobre a importância do "pensar sem corrimão" (Arendt) porque pensar sem Corrimãos é que é o pensar mesmo, olhando a própria coisa em seu devir necessário. Não se trata de um propósito moderno de hoje, não há nisso novidade alguma. Em torno a esse debate sobre a natureza dos textos, obras de palavras, que temos refletido a partir de Aristóteles: Se o ser se expressa de várias formas, será possível abarcá-lo por um único gênero de texto?

Segundo Aristóteles (1979), é a forma que lê a matéria e que lhe dá o acabamento. Assim como o escultor (causa eficiente) emolda/modela/talha a pedra, os poetas e os cientistas das ciências humanas esculpem as aparências vivas e únicas dos seres humanos, os únicos seres vivos que se perguntam pelo sentido de sua existência. Tanto estes como aqueles agem com uma finalidade, pois para Aristóteles tudo tem sua razão de ser, sua função e finalidade no cosmos: o vento para ventar, as flores para florir, o homem para ser feliz.

É assim também que temos buscado escrever com a mesma finalidade de um Dom Quixote: a de endireitar o torto e defender os desvalidos contra os moinhos de vento da existência não determinada dos homens. Dever ético e moral de todo e qualquer pesquisador ou pesquisadora. 


\section{Ciência ou literatura?}

Não sabemos ainda, mas sabemos alguma coisa. Sabemos, por exemplo, que na linguagem, essência da existência humana, tudo é possível até mesmo o inefável porque "Para o criador não há pobreza nem lugar mesquinho e indiferente" (RILKE,1997, p.23). Por isso nos mantemos atentos aos gêneros dos discursos humanos, às formas de dizer e pensar a palavra, o seu onde, o seu quando, o seu como e os seus porquês. Porém, não somos especialistas de nada. Diante dos fenômenos somos apenas leitores, um ser diante de outro ser, expressando-nos um ao outro na e pela linguagem. Na linguagem, não somos sujeito nem objeto, somos um encontro: um acontecimento mundano. É sobre esse acontecimento que temos ousado escrever borrando fronteiras entre estes e aqueles gêneros.

Em "Arte e Responsabilidade", Bakhtin (2017a) nos esclarece sobre a necessidade de cada indivíduo encontrar a sua unidade trinitária que o pensamento moderno disciplinou e hierarquizou entre conhecimentos científicos e não científicos, entre conhecimentos "verdadeiros" e conhecimentos do senso comum. Para Bakhtin, é essa segmentação disciplinar fundada na episteme moderna que tem afetado toda a existência sem álibi de cada indivíduo, resultando desde aí várias incompreensões a respeito do conhecimento de si mesmo e do mundo que lhe pesa nos ombros, desencadeando uma crise ética e epistemológica onde ninguém se sente mais responsável por. Segundo Bakhtin (2017a), o homem que está na vida não se sente responsável pelo homem que está na arte e vice-versa. É essa cisão que deve ser sopesada a fim de restabelecer a unidade que dá sentido à existência responsável de cada indivíduo.

Desse modo, é imperativo que tanto o poeta assim como o cientista compreendam que sua poesia, sua ciência têm culpa pela banalidade da vida e que, por outro lado, o homem da vida deve tomar consciência de que a falta de exigências e de seriedade nas questões vitais respondem pela esterilidade da arte e da ciência, pelo não-sentido da existência de cada indivíduo.

As palavras de Bakhtin nos levam ao âmago da questão e ao sentido do nosso pesquisar: restabelecer a unidade necessária entre as três esferas que compõem a cultura humana e na qual todos nos movemos de forma mecânica e, portanto, não responsável, porque, alheio ao compromisso ético de que todo o homem tem a ver com a vida de todos os homens. É a coisa que só pode acontecer no acontecer mesmo do aprender-viver entre os homens, no decorrer do nosso próprio viver.

Porque aprender a viver é que é o viver mesmo... Travessia perigosa, mas é a da vida. Sertão que se alteia e abaixa. O mais difícil não é um ser bom e proceder honesto, dificultoso mesmo, é um saber definido o que quer, e ter o poder de ir até o rabo da palavra. (ROSA, 2001, p.147)

A lição do romancista indica-nos o sentido de nosso pesquisar-viver no mundo-com- omundo. Daí nossa necessidade de ater-se aos três campos da cultura humana que estruturam a travessia perigosa e responsável do viver, mesmo que se expressa por e de vários modos. 
A literatura, a poesia, a ciência e a filosofia é que têm nos ensinado a ver, na vastidão dos gêneros textuais, a unidade do Ser-Aparecer dos indivíduos, pois é na e pela linguagem, conforme Bakhtin, que os homens se revelam, respondem uns aos outros de vários modos. $\mathrm{E}$ tudo o que dizem é de suma importância, porque tem sempre um sentido mesmo que seja de forma negativa e contrária ao que pensamos. O que vale dizer que compreender a palavra do outro não significa concordar, mas compreender é sempre necessário.

Estamos convencidos de que um pesquisador é um demiurgo, um artesão divino que traz consigo o princípio organizador do universo que, sem criar de fato a realidade, modela e organiza a matéria caótica preexistente e diversa da existência humana sem receita pronta, sem regras predeterminadas, pois a vida aos olhos de cada pesquisador ou pesquisadora é "Sertão que se alteia e abaixa... O mais difícil não é um ser bom e proceder honesto; "dificultoso mesmo é um saber definido o que quer, e ter o poder de ir até o rabo da palavra". É no contemplar da própria coisa que vemos as coisas mesmas como se fora a primeira vez, assim como Saramago em seu "Ensaio Sobre a Cegueira" imperativamente nos alerta: "Se puderes olhar, vê. Se puderes ver, repara".

E o que vemos quando vemos? Vemos o mundo com suas coisas feias e belas, coisas que nos fazem rir ou chorar, pois "quem conhece verdadeiramente o mundo, precisamente há de chorar, e quem ri, ou não chora, não o conhece" - foi o que disse Padre Antônio Vieira no sermão "Lágrimas de Heráclito", cujo trecho destaca-se abaixo para o deleite do leitor.

Entrando, pois, na questão, se o mundo é mais digno de riso ou de pranto, e se à vista do mesmo mundo tem mais razão quem ri, como ria Demócrito, ou quem chora, como chorava Heráclito, eu, para defender, como sou obrigado, a parte do pranto, confessarei uma coisa e direi outra. Confesso que a primeira propriedade do racional é o risível, e digo que a maior impropriedade da razão é o riso. O riso é o sinal do racional, o pranto é o uso da razão. Para confirmação desta, que julgo evidente, não quero mais prova que o mesmo mundo, nem menor prova que o mundo todo. Quem conhece verdadeiramente o mundo, precisamente há de chorar, e quem ri, ou não chora, não o conhece (2001, p.543).

É com esse olhar demasiadamente humano defendido por Viera, olhar que nos faz rir ou chorar, que temos reparado nas coisas que nos passam e temos nos perguntado sobre elas: o que se passa com as coisas que nos passam? Consentimos com Camus (2019, s.p.): "As coisas como estão não nos parece satisfatórias, os homens morrem e não são felizes" e que, portanto, "aquele que ainda ri [e não chora] é porque não recebeu a terrível notícia" (BRECHT, 2020, s.p.). Daí a necessidade Quixotesca de não apenas examiná-lo teoricamente, mas de transformá-lo como nos admoestou Marx (200\& em sua décima primeira tese sobre Feuerbach ${ }^{3}$. "O mais difícil não é um ser bom e proceder honesto, dificultoso mesmo, é um saber definido o que quer, e ter o poder de ir até o rabo da palavra" (ROSA, 2001, p.97)

Esse olhar humano coloca em questão os métodos tanto no campo das ciências humanas quanto no das ciências da natureza. Nestas últimas, cuja eficácia de seus procedimentos 
colonizou toda a prática científica, não há lágrimas nem riso, mas apenas conceitos e pensamentos abstratos. Nesse sentido, o homem de pensamento deve se manter neutro, incólume frente ao fenômeno que se manifesta à sua frente sem rir, sem chorar; deve apenas pensá-lo objetivamente, duvidando de tudo que lhes aparece aos sentidos: olfato, paladar, visão, audição e tato.

Segundo essa tradição platônico-cartesiana, no qual se pautam as epistemologias modernas, o mundo não tem gosto, não tem cheiro, não tem som, não tem tato, não tem visão; só tem medida e peso. Desse modo, o mundo então seria uma sombra que nos afasta da verdade fática e objetiva do seu aqui-agora. Tudo é dúvida. Tudo deve ser duvidado, porque as aparências nos enganam. Frente a elas, seguindo tal pensamento, nossos sentidos passam a não ser confiáveis. Justamente eles, os órgãos com os quais tangemos o mundo, somos noe-com-o-mundo.

Esta tradição da ciência moderna, cartesiana, dubitativa acabou nos levando a falácia de que, somente com métodos de investigação previamente concebidos, seríamos capazes de acessar o conhecimento verdadeiro sobre os seres. Certamente, tais métodos serviram, ainda servem para muitos cientistas e têm feito grandes progressos e descobertas, mas não servem de modo absoluto para se conhecer os indivíduos humanos. Os indivíduos não são coisas e, de modo algum, podem ser tratados como objetos, mas, como orienta Kant (2003), em "Metafisica dos costumes", fim em si mesmo.

Enfrentar a tensão entre os polos singularizante (a existência individual de cada ser humano) e o universalizante (a intenção de compreensão da sua essência) não faz das ciências humanas menos ciências que as demais ciências da natureza. Antes é aí que reside toda a sua riqueza, as possibilidades de se pensar o sentido do ser humano, indivíduos únicos e irrepetíveis, os mesmos, mas não exatamente em cada momento de seu existir no e com o mundo.

É nessa tensão, entre o singular e o universal, que buscamos compreender os gêneros textuais a partir de um olhar estético, ético e epistemológico. Trata-se de três modos de ver, de pensar e de organizar as experiências mundanas, com os quais procuramos ler vários gêneros de textos, os vários enunciados, considerando sempre, como Bakhtin e Aristóteles, que gêneros textuais são formas de esculpir o Ser.

Assim sendo, diante de cada indivíduo que sempre nos aparece de diversos modos na abertura de seu vir-a-ser, há de se ter um firme propósito, dada a natureza de seu inacabamento: o de se propor sempre de novo, com a novidade de ser cada vez a primeira vez, de modo responsivo e responsável, levando em consideração outras formas de compreender o mundo, de tal modo que o conhecimento não se resulte parcial, fragmentado pela especialidade ou pela adoção de um único ponto de vista.

Daí nos advém à ideia de adoção de uma heterociência, um tipo de ciência capaz de, pelo diálogo travado com os outros, abordá-lo na sua multiplicidade. Para o heterocientista, o mundo não é um absoluto, o mundo está sempre sendo e que, portanto, sobre ele é sempre possível tecer outras interpretações, de modo que homem ou ciência alguma detenha a última palavra. A questão não é somente epistemológica, mas ética, imperativa, categórica: a de não nos permitir que uma única visão prevaleça sobre as demais. É contra a tendência dos 
argumentos únicos da verdade do ser que nos mantemos em vigília para, assim, escapar às idolatrias dos nossos hábitos de pensamento fundado na adoção de métodos rígidos e inflexíveis que, por certo, não nos permitiriam ver as coisas no seu eterno vir-a-ser no seu ser-aí (dasein) fenomenal (HEIDEGGER, 1989).

Trata-se de considerar que as ciências humanas não são acumulativas como as ciências naturais que partem de um ponto de chegada, do já pensado anteriormente, mas, ao contrário, sempre de um novo ponto. Esse ponto não é o sujeito, como pensou Kant (2001) o sujeito do conhecimento, tampouco o objeto, algo a ser conhecido, mas a interação entre ambos, como nos ensinou Edmund Husserl (2001), na qual o objeto é também um sujeito que vê e é visto; eles se encontram, conversam, e daí a necessidade de se pensar sem corrimãos (ARENDT, 2019), sem métodos e sem conceitos prévios.

\section{Mas o que é o método?}

O método é o caminho, um caminho de vários caminhos a nosso dispor frente à abertura do ser no seu eterno devir. O método é a arte do fazer e do pensar, do fazer-pensando. O método é ato oriundo da potência criativa de seu criador no tecer-destecer as camadas do SerAparecer de todas as coisas. O método é o fio de Ariadne percorrendo um labirinto de linhas retas. Por ser assim tão reto como um labirinto, ele não é dado tampouco descoberto; ele é inventado no envolvimento com a coisa no ato mesmo que nos encaminhamos em direção à coisa que aparece à nossa consciência intencional, despertada pelos sentidos frente aos quais nos tornamos sujeito e objeto. Nesse sentido, nosso método fenomenológico é afetivo, porque nos afeta quando o afetamos com nossa consciência intencional. Se não for assim, não é ainda um bom método porque incapaz de captar a epifania do ser nos entes. É com o corpo, e não só com o intelecto que percebemos o SER de cada coisa que tocamos e somos tocados, mobilizados e entramos em diálogo. O método é o jeito como bolinamos a coisa e somos também bolinados por ela. $\mathrm{O}$ nosso jeito de perceber a coisa é que faz a coisa e sermos alterados por ela. A coisa que se mostra não é apena um objeto; ela é também um sujeito em relação a mim. Sou também seu objeto. A coisa objeto é sujeito que fala comigo sobre o seu inefável. É o inefável da coisa que nos impele ao escrever sobre o é da coisa na própria coisa, coisas-pensamento ressignificadas pelo intelecto no corpo e na alma, na consciência. $\mathrm{O}$ método é caminho que não é, é verbo que parte do nada para o nada em busca da coisa que nunca é porque não pode deixar de ser, pois é tempo que não para, de modo que nunca vemos a coisa, mas seu movimento em ato e potência. Concordamos com Heráclito e também com Parmênides, sobretudo com Aristóteles, porque não se pode ver a coisa duas vezes: o ser se diz de vários modos.

Nossas pesquisas não são sobre os indivíduos, mas com os indivíduos únicos, irrepetíveis e inacabáveis. Assim o sendo

A qualidade da luz pela qual examinamos nossas vidas tem influência direta sobre o produto que vivemos e sobre as mudanças que esperamos trazer através dessas 
vidas. É dentro dessa luz que formamos as ideias pelas quais buscamos nossa mágica e a realizamos. Isto é poesia como uma forma de iluminação, pois é através da poesia que damos nome àquelas ideias que são, até o surgimento do poema, sem nome e sem forma - prestes a nascer, mas já sentidas. Essa destilação da experiência a partir da qual a verdadeira poesia origina o nascimento como conceito de nascimento dos sonhos, como sentimento de nascimento, à medida que o conhecimento nasce (precede) o entendimento. (LORDE, 2019, p.45)

O certo é que o princípio organizador de qualquer encontro é o caminhar do próprio encontro entre dois seres humano. O princípio nunca é dado, mas construído dialogicamente entre um Eu e um TU. Todavia podemos dar início a um diálogo, mas jamais prever ou controlar seu resultado; este será sempre dado a posteriori no acontecer do acontecimento mesmo. O encontro entre dois sujeitos é o momento que nos convoca sempre a perguntar pelo sentido do ser no seu constante vir-a-ser. Encontro de dois mundos que se encontram, o mesmo mundo sobre o qual se conversa, mas não exatamente. $\mathrm{O}$ que pensa o outro sobre o mundo? Qual sentido que ele lhe empresta com seu olhar? Sendo assim, em nossas pesquisas o encontro com outro é sempre um novo encontro, único, irrepetível, singular, em que buscamos, como Drummond (2012, p.11) desenfeitiçar as palavras para penetrá-las surdamente em seu reino às vezes congelados nos calabouços de seus verbetes dicionarizados e devolvê-las à vida cotidiana, pois é aí que elas se reencarnam e ganham novos sentidos. São elas que enunciam, organizam o mundo que o decifram e colocam novas questões que esperam ser respondidas.

Por esse e outros motivos, ousamos dizer que pesquisa não se ensina, antes, se aprender no exercício do seu labor. É a pesquisa que forma o pesquisador que a realiza. Desse modo, não cremos que se possa se formar tão somente a partir de conceitos abstratos, mas no âmbito do próprio fazer-pensar. Assim, como Comenius (2001) concebeu a didática dos meninos e meninas, nós também a temos em mira para formação dos pesquisadores e pesquisadoras, qual seja: que o aprendizado do pesquisar não seja feito apenas por um modo teórico, mas prático e contínuo; que ao aprendiz seja dada a chance de aprender de modo direto, concreto e prático; que o pesquisador aprenda a pensar, pensando e por si mesmo. Sem corrimãos!

A passagem acima escrita nos remete a Bakhtin, filósofo e crítico de arte que nos orienta e que nos fundamenta e que, por outras palavras, também nos diz que arte, vida e conhecimento só podem adquirir unidade no indivíduo que a incorpora. É nessa unidade indivisa que o pesquisador ou pesquisadora se depuram no fazer da sua arte, de seu conhecerviver.

\section{Em busca da práxis / heterociência}

Para dar notícias dessa vida "Sertão que se alteia e abaixa..." (ROSA, 2001, p.778), passaremos a narrar a história de uma pesquisa, ou melhor, a história que vivenciamos com Patrícia ${ }^{4}$ no decorrer da escrita de sua dissertação. 
A pesquisa de Patrícia aconteceu em uma Escola de Educação Infantil pertencente a uma Universidade Pública. Seu desejo era tratar das práticas pedagógicas que colocam as crianças em seu centro e reconhecem o potencial criador que esse grupo traz para o mundo, reinventando-o a seu modo a partir do recebido. Sempre que uma criança nasce, e elas nascem todos os dias, o novo entra no mundo, porque toda crainça é o vir-a-ser do mundo, por isso a educação, segundo Hannah Arendt (2010), tem a ver com o nascimento de uma criança, com o nascimento de cada criança que, por certo, traz a pergunta sobre o ser ou não ser do seu puro aparecer entre os homens, entre todas as pessoas que o antecederam. Para Hannah Arendt, nascer é isto: aparecer entre os homens.

Um dia Patrícia nos apareceu! A questão que sempre nos vem, ao receber um novo membro em nosso grupo, é o de perguntar sempre de novo sobre qual o sentido de sua pesquisa, pelo seu verdadeiro querer pesquisar. Com Patrícia não foi diferente. Como orientála sem fazer por ela o que a ela lhe cabia inteiramente fazer de forma responsável, de modo que sua pesquisa produzisse um conhecimento digno da produção acadêmica e que afirmasse seu compromisso não só pelos conhecimentos científicos, mas também com a arte e com a vida.

E foi nessa primeira conversa com Patrícia que ela tomou conhecimento de que ninguém poderia aconselhá-la ou ajudá-la; que não havia caminho algum a ser seguido, porque que ele se fazia no decorrer do próprio pesquisar e que, portanto, não tínhamos mapa nem receita pronta que pudéssemos oferecê-la naquele momento. $\mathrm{O}$ caminho teria que ser feito por ela mesma. Advertimos Patrícia do mesmo modo que Rilke (1997) advertiu a Kappus, o jovem que queria ser poeta. As palavras de Rilke foram as nossas palavras. Palavras que copiamos ipsis litteris:

Ninguém pode aconselhá-lo e ajudá-lo, ninguém. Há apenas um meio. Volte-se para si mesmo. Investigue o motivo que o impele a escrever; comprove se ele estende as raízes até o ponto mais profundo do seu coração, confesse a si mesmo se o senhor morreria caso fosse proibido de escrever. Sobretudo isto: pergunte a si mesmo na hora mais silenciosa de sua madrugada: preciso escrever? Desenterre de si mesmo uma resposta profunda. E, se ela for afirmativa, se o senhor for capaz de enfrentar essa pergunta grave com um forte e simples "Preciso", então construa sua vida de acordo com tal necessidade; sua vida tem de se tornar, até na hora mais indiferente e irrelevante, um sinal e um testemunho desse impulso. Então se aproxime da natureza. Procure, como o primeiro homem, dizer o que vê e vivencia e ama e perde ... (p.22).

\section{Narrativa de uma pesquisa}

Achamos que Patricia entendeu, porque se pôs a trabalhar, a se dizer de vários modos. Assim como são as crianças, ela excedia, se esparramava, extravasava sem formas rígidas e inflexíveis, uma vez que se dizia de vários modos e que redundaram em sua dissertação defendida no ano da graça de 2020, ano da pandemia. É essa resposta responsánvel e 
responsiva que procuramos demostrar aqui... o cotidiano de nossas pesquisas. Por isso mesmo, deixemos que ela fale a partir de sua própria dissertação, pois é na e pela linguagem que Patrícia se revela. Logo, na seção "Sobre gatos e Passarinhos", Patricia, hoje a pesquisadora, nos fala de sua infância passada em um subúrbio carioca...

.... faço, aqui, um pequeno recorte para falar da minha infância, do espaço tempo de minha aprendizagem que começou num terreno baldio na Pavuna, num bairro do subúrbio da cidade do Rio de Janeiro, um território livre da presença de adultos "experientes", que, com a doce e sincera intenção de nos proteger, provavelmente, nos tolheriam de tão ricas experiências lá vivenciadas. (Caderno de notas do autor).

Mas por que Patrícia passou toda sua infância naquele terreiro baldio? Que mistérios terá a infância de Patrícia? poderão nos perguntar. Eis a resposta provável: não era só Patrícia que brincava assim; muitas outras crianças da mesma idade passavam seus dias do mesmo modo, brincando ao ar livre nos arredores de casa, nos recantos dos bairros. Naquele tempo, as crianças não corriam tanto perigo, não precisavam temer nem tremer de medo de balas perdidas e de carros da polícia. Era um tempo em que as crianças brincavam despreocupadas nas ruas, nas calçadas, e seus pais deixavam, mas não todos. Os pais de Patrícia a deixavam brincar lá naquele terreno baldio em que ela tudo aprendera: soltar balão, fazer fogueira, jogar bola, pular corda, brincar de roda, de casinha com bonecas sem braços e panelas furadas.

É que naquele tempo das infâncias de terrenos baldios, ruas e calçadas, os chamados de "Jardim de Infância", escolas para educação infantil, eram escassos e raros, e os poucos que havia eram instituições particulares pagas. $\mathrm{O}$ acesso era só para quem pudesse pagar pelo serviço. Os pais de Patrícia, assim como de muitas outras crianças, não tinham dinheiro o bastante para arcar com os custos da escola. Jardim era um luxo que só a poucas crianças cabia. Patrícia não era uma delas; fazia parte da maioria. Sem "Jardim”, fez se o seu próprio Jardim onde havia um terreiro baldio que os adultos pensavam não haver nada. Lá Patrícia não deixou de aprender o que tinha de aprender e, sobretudo, não deixou de brincar com seus companheiros e companheiras, meninos e meninas da sua rua. Por isso Patrícia, hoje professora, escreve em sua dissertação de mestrado sobre o aprendizado obtido naquele tempo e lugar que nenhum adulto via, porque não tinha a capacidade de ver e reparar nas possibilidades de um terreiro baldio, lugar vazio mas cheio de tudo que para lá vazasse. Toda vaza era humana: pé-de-sapato, meias-furada, cadeira-quebrada, mesa-sofás, ampolas de penicilina, espelhos partidos, bule, chaleira, cabeleira de carnaval e milhões de outras quinquilharias.

Em sua dissertação, Patrícia - obedecendo a Rilke - nos relembra as vicissitudes daqueles dias passados, guardadas em sua memória:

...lá desenvolvia minhas experiências com todos os materiais que o lugar oferecia. Era baldio para os adultos, mas não era para nós. O que era lixo, num piscar de olho virava brinquedo e brincadeira que nossa imaginação esculpia em forma de brinquedo - do inútil do útil e do útil ao lúdico. (Caderno de notas do autor) 
Com olhar úmido de saudade, Patrícia medita sobre a riqueza daquelas misérias descartáveis com as quais brincava e aprendia sem ser ensinada, fazendo artes de sucatas.

Nossos brinquedos eram feitos de latas velhas, máquinas de escrever, cabos de vassoura, potes, terra, pedras, restos das construções de coisas desamadas. Todas aquelas coisas eram milagres que transformavam em foguetes, bonecas, espadas, bolas, carrinho, casinhas e castelos... Brincávamos de princesas, príncipes e dragões. Erámos nós mesmos nossos super-heróis. Não, o nosso terreiro baldio não era baldio... Ao contrário, tinha tudo que uma criança precisa para brincar, interagir e superar desafios e aprender a viver no-com-o-mundo. Meu mundo eu catei naquele lixo das crianças sem Jardim, mas nunca sem infância. São muitas infâncias em que cada criança é uma. (Caderno de notas do autor)

Nesta passagem a pesquisadora reconhece a riqueza daquela relação... "Quanto aprendizado!"- exclama ela, lembrando-se do currículo que nem sabia que havia e que sem saber aprendera. Aprendera que é da infância que resultamos todos nós porque "a criança é o Pai do homem" - conforme W. Wordsworth. Uma afirmação e tanto que outros poetas repetiram, como por exemplo, Machado de Assis em "Memórias de Brás Cubas"

E o que Patrícia aprendera com aquela menina dos terrenos baldios?

Aprendera que a brincadeira é a Potência em Ato manifestada em cada criança, em cada indivíduo. É a criança que ainda hoje a habita que a mantém em estado (de) curiosidade em meio aos folguedos de seus pensamentos. Ouçamos a voz de Rilke (1997) quando escreve a Kappus, o jovem que lhe pedira conselhos sobre a escrita da poesia. A passagem da carta nos mostra, de modo bastante claro, o potencial da criança e que se manifesta no ato-potente de brincar.

[...] Mesmo que estivesse em uma prisão, cujos muros não permitissem que nenhum dos ruídos do mundo chegasse a seus ouvidos, o senhor não teria sempre a sua infância, essa riqueza preciosa, régia, esse tesouro das recordações? Volte para ela à atenção. Procure trazer à tona as sensações submersas desse passado tão vasto; sua personalidade ganhará firmeza, sua solidão se ampliará e se tornará uma habitação à meia-luz, da qual passa longe o burburinho dos outros. E se, desse ato de se voltar para dentro de si, desse aprofundamento em seu próprio mundo, resultarem versos, o senhor não pensará em perguntar a alguém se são bons versos (p.23).

Pulando para o outro tempo guardado na memória, Patrícia recorda, pensa...

Ali, com meus amigos, aprendi a selecionar; introduzindo os conceitos de conjunto; aprendi a contar, apendi as noções básicas das quatro operações aritméticas: somar, dividir, diminuir e multiplicar. Aprendi a lidar com os fenômenos da natureza, pois, se chovia, impunha-se cobrir os brinquedos e as 
brincadeiras; se ventasse muito forte, era preciso colocar um peso ou prender para que os objetos não voassem. Aprendi a respeitar e ouvir uns aos outros. Aprendi companheirismo: se um caísse ou se machucasse, imediatamente, era socorrido. (Caderno de notas do autor)

Com os olhos iluminados pela saudade de sua infância, continua a suspirar:

Ah... Assim eram os dias de trocas de ideias e ouvindo com atenção a ideia de cada companheiro. Os problemas eram resolvidos. Havia confiança e laços de solidariedade... Voltando da realidade de seu sonho sublinha: Ali naquele terreno baldio só não havia adultos para ordenar e por ordens ao livre pensar das crianças! (Caderno de notas do autor)

De repente lhe vieram à cabeça as palavras de Benjamin (2002). Esbraveja em defesa da liberdade de pensar das crianças que nós adultos teimamos educar.

Travamos nossa luta por responsabilidade contra um ser mascarado. A máscara do adulto chama-se "experiência". Ela é inexpressiva, impenetrável, sempre a mesma. Esse adulto já vivenciou tudo: juventude, ideias, esperanças [...]. Talvez ele tenha razão. O que podemos objetar-lhe? Nós ainda não experimentamos nada. (p. 21)

E só foi por causa disto, das palavras escritas num livro de Benjamin (2002), que Patrícia escreveu em favor de todas as crianças em seu texto de dissertação. Não sem problemas, é claro.

O problema de Patrícia era e ainda é a dificuldade de muitos: o de escrever com rigor, clareza e leveza de modo que pudesse contar as experiências das crianças com as quais trabalha, na verdade brinca, porque brincar é o busílis do aprender-viver de uma criança, uma força criativa que também nos habita. Brincar era também para ela tirar a máscara impenetrável de adultos para, assim, se aproximar das crianças sem manipulá-las. Brincar foi o método que adotou. Brincar com as crianças e depois narrar as peripécias desses encontros na forma de crônicas, mas obedecendo tudinho às regras da academia.

O texto acadêmico não era brincadeira, mas, acostumada a brincar com sucatas, deu logo seu jeito e resolveu escrever crônicas. Achava que esse gênero era mais adequando para registrar o cotidiano das crianças com quem brincava e aprendia tal qual antigamente. Mas, mesmo assim convencida, tratou de escapar aos olhares dos adultos, pessoas essas que, segundo Antoine de Saint-Exupéry (2009), não sabe distinguir o desenho de um chapéu do desenho de uma jiboia que engole elefante. Leia o que ela nos escreve logo no início de sua dissertação, com medo de puxões de orelhas ou ter que se ajoelhar em caroços de milho.

Para que o leitor desavisado não se confunda, afirmamos: esse texto é uma dissertação. Não que não quisesse ser cronista da escola e das crianças, mas pela limitação literária que me acomete e pela demanda acadêmica que precisava 
atender. Então uma vez esclarecido esse ponto de partida, continuemos a fazer o que é de gosto: vamos contar as coisas sem pressa e com gostinho de conversa com café na mesa da cozinha. (Caderno de notas do autor)

Dito isso, pegou logo um livro que tratava do assunto e destacou a seguinte passagem de Castello (2007), usada por ela como defesa de sua opção de escrita de sua dissertação:

Nas fronteiras longínquas da literatura, ali onde os gêneros se esfumam, as certezas vacilam e os cânones se esfarelam, resiste a crônica. Nem todos os escritores [eu diria pesquisadores] se arriscam a experimentá-la, e os que o fazem se expõem, muitas vezes, a uma difusa desconfiança. Para os puristas, a crônica é um "gênero menor". Para outros, ainda mais desconfiados, não é literatura [ou pesquisa científica], é jornalismo - o que significa dizer, simples registro documental. Alguns acreditam que ela seja um gênero de circunstância, datado oportunista. Não é fácil praticar a crônica. (p.2) (As notas entre colchetes são da autora).

Mas Patricia não estava só interessada em justificar o gênero de sua dissertação. Era também prudente esclarecer que sua pesquisa não era apenas uma brincadeira de conversa na cozinha, mas também fruto de seu estudo de seu amadurecimento intelectual. Patrícia estudava Bakhtin e foi com esse autor que ela passou da brincadeira à reflexão sem, no entanto, perdê-la de vista. Então falou aos seus interlocutores sobre o que ela aprendera com este autor sobre pesquisa. Fazendo das palavras dele, suas palavras, encarnando-as em seu texto.

Aprendi com Bakhtin que nas ciências humanas precisamos considerar a relação de pessoas: uma que quer saber sobre outra que fala sobre o que quer falar. $\mathrm{O}$ pesquisador lida com sujeitos expressivos, falantes. Quem pergunta o faz diretamente àquele que pretende conhecer (2011, p. 394). (BENTO, 2020, p. 23)

É esse encontro amoroso com o outro, acontecimento único e irrepetível, visto por Patrícia sempre como se fosse pela primeira vez, que ela registrou em seu texto e defendeu, justificando, destarte, como manda o figurino das regras acadêmicas, sua perspectiva de ciência, que não era só ciência, mas arte e vida.

Pôr em cena a dimensão estética, conjugada à ética e epistemológica traduz a tripla dimensão da cultura - arte, vida e conhecimento e vai marcar os atos como irrepetíveis e de total responsabilidade do sujeito. E essa unidade indissolúvel cuja síntese está em cada sujeito que a incorpora responsavelmente sem delegar a outrem o que lhe compete fazer - que a aventura heterocientífica nos impõe outras formas de dizer, de dissertar, de narrar, de modo que possamos abarcar de modo plural as experiências mundanas.” (BENTO, 2020, p. 23) 
E para dar mais legitimidade ao que acabara de escrever termina seus argumentos com uma passagem do texto de Bakhtin: "Arte e vida não são as mesmas coisas, mas devem tornar-se algo singular em mim, na unidade da minha responsabilidade" (2017, p. XXXIV).

E, nesse ponto, temos certeza de que Patrícia nos compreendeu e se fez compreender... Leve, livre e solta passa a nos descrever o espaço físico no qual se desenrolou toda sua pesquisa brincando com as crianças, feito uma apresentadora de circo bem a gosto da meninada.

O espetáculo vai começar, cenário pronto, personagens a postos, com suas falas ensaiadas e na ponta da língua, figurinos definidos, tudo certo para encantar a plateia. Então: luzes, câmeras e ação! (AUTOR, 2020, p. 50)

Dito isto, mais vez, admoesta os espectadores-leitores para que não comprem "gatos por lebres", para que não leiam uma coisa em lugar de outra, pois Patrícia sabia que se tratava de uma dissertação de mestrado e que o circo era uma metáfora da vida vivida no conluio entre arte e ciência que sempre existe no simples brincar de uma criança. Ato-potência do seu desenvolvimento. Mas Patrícia estava receosa de que, talvez, os adultos também confundissem jiboia que almoça elefante com um simples chapéu de feltro. Então fala com a voz grave

Não! O que o leitor vai apreciar agora não é um romance ou uma novela ou uma peça teatral. A obra aqui narrada, fala de vida, de arte e de produção de conhecimento. O cenário em que essa história se passa é lugar de árvores frondosas, com troncos robustos que parecem pedir um abraço, raízes salientes sobre o solo. A iluminação é natural! Céu azul, ou branco, ou cinza... Pergunte às crianças qual é a cor do céu. Difícil descrever a vastidão do espaço. Lugar fabuloso para a heterociência de que fala Beto, Bakhtin e Flávia. E que naquele solo fértil brotaram-nos ideias que emanavam sentimentos e emoções que aguçavam a curiosidade das crianças - cientistas por natureza. Acontecimentos da vida real. Os fatos aconteceram. Não são ficção. (BENTO, 2020, p. 50)

Trata-se de uma obra dialógica, pois é por meio do diálogo com as crianças que a professora-pesquisadora, ao longo de três anos, cantou, jogou, correu, enfim tratou de conhecer a cultura delas, conversando a partir das brincadeiras que inventavam ou aconteciam de repente inesperadamente. Naquela escola, Patrícia reinventava junto àquelas crianças tudo que aprendera naquele terreno baldio. Em vez de perguntas, inventava brincadeiras, porque brincar era o jeito próprio de cada criança se dizer por vários modos e aprender sem ser ensinada, e ir "até o rabo das palavras". (ROSA, 2001, p.147). Patrícia sabia que não era ir aos dicionários ou a algum livro que, porventura, tratasse do assunto. Ao contrário, preferiu conversar diretamente com cada uma delas sobre suas infâncias, olhando no rosto de cada uma delas; preferiu ver, em cada criança que ri e que chora no processo de conhecer o mundo, esse imenso terreiro baldio cheio de possibilidades e de aprendizado. 
Aos olhos de Patrícia, a criança é o centro de sua investigação. Para ela, a criança é indivíduo único e irrepetível que age, pensa e fala por si mesmo, participando por inteiro do seu aprender-viver-fazer conforme desejado por Comenius. A criança para Patrícia não é um meio, mas um sujeito e, portanto, um fim em si mesmo e, como tal, deve ser considerado na e pelas suas palavras.

$\mathrm{Na}$ teia das relações dialógicas que tece, é possível perceber uma escuta séria e responsável que leva em conta todas as opiniões, contrárias ou favoráveis a um dado ponto de vista. Os personagens vão ganhando forma, não apenas pela sua aparência, mas principalmente pelo poder dos seus argumentos, suas ideias e discurso, pois a palavra tem valor.

Deixemos que Patrícia nos fale (BENTO, 2020, p. 50-52).

\section{Autor/Herói - Autora/Professora. Um ato responsivo}

Deixamos aqui registrado uma tarde de brincadeiras no pátio da escola esperando com isso demostrar que pesquisar não é preciso e viver também não.

... Nesse dia, as bolas ganharam a atenção das crianças. Bola pra cá, bola pra lá. Até que, numa jogada inesperada, a bola azul foi parar ao pé da árvore presa às suas folhagens. Percebi o movimento próximo à bola. Júlia ${ }^{5}$ me procurou, pedindo:

- "Patrícia, pega a bola pra mim"?

Perguntei por que ela mesma não a pegava. Com um olhar ressabiado, Júlia se aproximou e segurando a minha mão respondeu:

- "Eu não".

Observei o comportamento, que traduzi como medo, e procurei encorajá-la:

- "Vai lá, Júlia, pega você mesma, eu estou aqui te olhando"! Em vão. Júlia naquele momento falava mais com os olhos do que com as palavras, apertava a minha mão e movimentando a cabeça negativamente respondia:

- "Não, pega pra mim".

Outras crianças ficaram em volta, parecendo esperar alguém para resolver o problema pegando a bola. Sugeri à Júlia falar com os colegas. Lá foi a menina falar com o grupo já iniciando o envolvimento em outras brincadeiras. À distância, o movimento das crianças revelava desinteresse pela bola azul. Júlia voltou chateada. De repente, para a nossa surpresa, Roberto veio em seu socorro:

- "Eu pego! Eu pego! Deixa que eu pego".

As crianças surpreendem. Não esperava que justamente o Roberto, menino pouco afeito ao inesperado resolvesse o problema da bola azul. Com um perfil delicado, era usuário recorrente da linguagem do choro ao invés da das palavras em suas comunicações. Justamente ele veio cheio de certeza e disposição, empurrou com as mãos as folhagens da árvore e, bravamente, resgatou a bola azul.

Arquitetônica, acabamento, autor, herói, ética, estética são elementos da obra intimamente ligados. $\mathrm{O}$ autor é responsável pelo todo da obra e, principalmente, pelo 
personagem que precisa viver de forma ética e cognitiva, pois gira em torno dele a busca por uma equipolência de vozes. Ética e estética não podem ser pensadas separadamente, se a estética se refere ao fazer artístico, o conceito de ética está ligado ao plano da vida "discurso na vida, discurso na arte" (Gege, 2009 p. 42); a ética está comprometida com o ato de agirmos no mundo. Nossa maneira responsiva e responsável de interagir com nossos interlocutores.

Como na vida, por meio do discurso, vamos nos apresentando e ocupando o nosso lugar no mundo. Júlia me procurou para resgatar a bola presa na árvore. Buscamos outras soluções. Roberto, solidário, se envolveu na trama e resolveu a questão. Se Júlia não falasse comigo, se eu não a escutasse, se Roberto não se importasse... "se", "se" e "se". Que perigo se o diálogo não se instaurasse.

Exotopia e polifonia estão presentes na aproximação eu/outro, professora/criança, pesquisadora/criança e, por que não dizer, autora/personagens.

Racionalmente, o adulto não compreende o temor da criança que se recusa a buscar a bola. Eticamente, o adulto a acolhe.

Eu devo entrar em empatia com esse outro indivíduo, ver axiologicamente o mundo de dentro dele tal qual ele o vê, colocar-me no lugar dele e, depois de ter retornado ao meu lugar, completar o horizonte dele com o excedente de visão que desse meu lugar se descortina fora dele, convertê-lo, criar para ele um ambiente concludente a partir do excedente de minha visão, do meu conhecimento, da minha vontade e do meu sentimento. (BAKHTIN, 2017 p.23).

Esse movimento exotópico levou a adulta ao que as crianças esperavam dela e ao que ela podia esperar das crianças. O gesto implicou numa ação, um ato responsivo e responsável que apenas um, do seu lugar, podia assumir.

Bakhtin (2017b, p. 23) assevera que, nessa arquitetônica, três momentos são fundamentais: "eu-para-mim, eu-para-o-outro, o outro-para-mim". O encontro do Eu, em sua singularidade, com o Outro, que apresenta igualmente uma singularidade, também é o que faz o evento-existir, um acontecimento único e irrepetível.

Como vida, arte e conhecimento não são as mesmas coisas, mas podem e devem caminhar juntas, faço aqui um exercício de mergulhar na transgrediência dos dias na Escola de Educação Infantil e pensar numa nova arquitetônica para o fazer pedagógico numa pedagogia da infância. "A ciência, a arte, a vida adquirem unidades somente na pessoa que as incorpora na sua unidade" (BAKHTIN, 2017b p.21).

Dessa forma, ao escrever as crônicas que compuseram a dissertação, a pesquisadora construiu uma autobiografia. Falou de si e do outro, foi impactada e sofreu o efeito constitutivo dos encontros. Ao organizar, no texto escrito, as vivências da professora, o fez numa perspectiva estética, descrevendo uma vivência ética. Nessa transgrediência buscou o alargamento da consciência, porque, ao se colocar à margem de si mesma, se enriqueceu de valores transgredientes (SOUZA e MIOTELLO, 2018 p. e ponto final! 


\section{Considerações finais}

Uma das teses defendidas neste texto foi a de pensar, mas de "Pensar sem corrimãos", porque o importante é pensar, e pensar livre como quem "Reparasse que nascera deveras... Com olhar nítido de girassol, mas com a questão de Hamlet: To be, or not to be, that is the question, Ser ou não ser, eis a questão.

Quando fala um dos grandes, como Shakespeare, que só uma vez aparecem, os pequenos devem calar-se! Parar para pensar o próprio pensamento, mesmo sabendo que

O pensamento não traz conhecimento como as ciências. O pensamento não produz sabedoria prática utilizável. O pensamento não resolve os enigmas do Universo. $\mathrm{O}$ pensamento não nos dota diretamente com o poder de agir. (Heidegger apud Arendt ${ }^{6}, 2009$, p.17)

O pensamento só se ocupa com ele mesmo... "o resto é silêncio..." Hamlet".

Ao realizar sua escrita na perspectiva de uma ciência outra, Patrícia "alargou" o gênero acadêmico, construindo o rigor heterocientífico. Patrícia pôde "pensar sem corrimões" e, dessa forma, produziu um saber que tal como a cultura permite espalhar/espelhar, arte, vida e conhecimento.

\section{Notas:}

1. Afresco, pintado de 1509 a 1510. Stanza della Segnatura (Vaticano). Disponível em: https://www.dm.ufscar.br/hp/hp902/hp902001/hp902001.html acesso em 07/08/2020.

2. Frase de René Descartes em "O Discurso do Método" (1973).

3. Escrito por Marx durante a primavera do 1845. Redigido e publicado pela primeira vez em 1888, por Engels como apêndice da edição em folheto à parte de seu Ludwig Feuerbach. Publica-se de acordo com o texto da edição em folheto à parte, de 1888, após confronto com o manuscrito de Marx. Traduzido do espanhol.

4. Os nomes apresentados são fictícios.

5. Os nomes utilizados são fictícios.

6. Arendt não explicita de onde esse trecho foi retirado.

7. "O resto é silêncio" é a última fala de Hamlet à beira da morte.

\section{Referências}

ANDRADE, C. D. de. Nova Reunião. José Olympio Editora - Rio de Janeiro, 1985.

ANDRADE, C. D. de. A Rosa do Povo. Companhia das Letras: São Paulo, 2012.

ARENDT, H. A condição humana. 11a. ed. rev. Rio de Janeiro: Forense Universitária, 2010.

ARENDT, H. Pensar sem corrimões. Lisboa: Relógio d'água, 2019.

ARISTÓTELES. Ética a Nicômaco. In: Os Pensadores vol. II. Trad. Leonel Vallandro \& Gerd Bornheim da versão inglesa de W.D. Ross. São Paulo. Abril Cultural, 1979. 
BAKHTIN, M. Estética da criação verbal. 6ª ed. São Paulo: Martins Fontes, 2017a.

BAKHTIN, M. Para uma filosofia do ato responsável. $3^{a}$. ed. São Carlos: Pedro e João Editores, $2017 \mathrm{~b}$.

BENJAMIN, W. Reflexões sobre a criança, o brinquedo e a educação. São Paulo: Editora 34, 2002.

BENJAMIN, W. Teses Sobre o Conceito da História. In: LÖWY, M. Alarme de Incêndio: uma leitura das teses sobre o conceito de História. São Paulo: Boitempo Editorial, 2005.

BENTO. P. K. P. Pedagogia e escuta responsiva - a cultura da infância na EEI - UFRJ: por práticas pedagógicas dialógicas. 2020, 203f. Dissertação (Mestrado em Educação) - Programa de Pós-Graduação em Educação, Contextos Contemporâneos e Demandas Populares, Universidade Federal Rural do Rio de Janeiro, 2020.

BRECHT, Bertold. Aos que vierem depois de nós. In: Releituras. Disponível em: http://www.releituras.com.br/bbrecht_aosquevierem.asp. Acesso em 08/08/2020.

CAMUS, Albert. O mito de sísifo. Editora Record: São Paulo, 2019.

CASTELLO, José. Crônica, um gênero brasileiro. Rascunho, Curitiba, set. 2007.

COMENIUS, John A. Didática Magna. 3. ed. - São Paulo: Martins Fontes, 2002.

DESCARTES, René. Discurso do método. Coleção Os pensadores, vol. XV. Trad. J. Guinsburg e Bento Prado Jr. São Paulo: Abril Cultural, 1973. p. 33-80.

GEGe - Grupo de Estudos dos Gêneros do Discurso. Palavras e contrapalavras: glossariando conceitos, categorias e noções de Bakhtin. São Carlos: Pedro \& João Editores, 2009.

HEIDEGGER, Martin. Ser e tempo (v. I). Petrópolis, RJ: Vozes, 1988. (Trabalho original publicado em 1927).

HEIDEGGER, Martin. Ser e tempo (v. II). Petrópolis, RJ: Vozes, 1989. (Trabalho original publicado em 1927).

HUSSERL, Edmund. Meditações cartesianas: introdução à fenomenologia. São Paulo: Madras, 2001.

KAPPUS, Franz Xaver. Introdução das Cartas a um jovem poeta. In: RILKE, Rainer Maria. Cartas a um jovem poeta. São Paulo: Editora Globo, 1997.

KANT, Immanuel. Crítica da razão pura. Lisboa: Fundação Calouste Gulbenkian, 2001.

KANT, Immanuel. A metafísica dos costumes. Bauru, SP: EDIPRO, 2003.

LORDE, Audre. A irmã outsider. Belo Horizonte: Autêntica, 2019.

MARX, Karl. Teses sobre Feuerbach. In: MARX, Karl.; ENGELS, Friedrich. A ideologia alemã. Trad. Marcelo Backes. Rio de Janeiro: Civilização Brasileira, 2007, p. 27-29.

ROSA, João Guimarães. Grande Sertão: Veredas. 19. ed. Rio de Janeiro: Nova Fronteira, 2001.

RILKE, Rainer Maria. Cartas a um jovem poeta: a canção de amor e de morte do porta-estandarte Cristóvão Rilke. Tradução de Paulo Rónai e Cecília Meireles. São Paulo: Globo, 1997.

SARAMAGO, José. Ensaio sobre a cegueira. Companhia das Letras: São Paulo, 1995.

SAINT-EXUPÉRY, Antoine de. O pequeno príncipe. Rio de Janeiro, Editora Agir, 2009. Aquarelas do autor.

SOUZA, N. B. de; MIOTELLO, V. Vivenciar a si mesmo à margem: transgrediência, acabamento, opacidade. In: SERODIO, L. A.; SOUZA, N. B. de. (orgs.). Saberes transgredientes. São Carlos: Pedro \& João Editores, 2018.

VIEIRA, Antônio. Sermões. Tomo II. Organização e introdução Alcir Pécora, São Paulo: Hedra, 2001.

VOLÓCHINOV, Valentin. Marxismo e filosofia da linguagem. Problemas fundamentais do método sociológico na ciência da linguagem [1929]. Tradução do russo de Sheila Grillo e Ekaterina Vólkova Américo. São Paulo: Editora 34, 2017. 


\section{Correspondência}

Carlos Roberto de Carvalho: Doutor em Educação pela Universidade Federal Fluminense. Professor do PPGEduc/UFRRJ. Coordenador de GEPELID - Grupo de Estudos e Pesquisa sobre Linguagem e Diferenças.

E-mail: carlosbeto.carvalho@ gmail.com

Orcid: https://orcid.org/0000-0003-3408-134X

Flávia Miller Naethe Motta: Doutora em Educação pela Pontifícia Universidade Católica do Rio de Janeiro. Professora do PPGEduc/UFRRJ. Coordenadora do GEPELID - Grupo de Estudos e Pesquisa sobre Linguagem e Diferenças.

E-mail: flaviamnmotta@gmail.com

Orcid: https://orcid.org/0000-0001-8538-8865

Patricia Kersch Pedrosa Bento: Mestre em Educação pelo PPGEduc/UFRRJ. Membro do GEPELID - Grupo de Estudos e Pesquisa sobre Linguagem e Diferenças.

E-mail: patriciakerschr@hotmail.com

Orcid: https://orcid.org/0000-0001-6845-4058

Texto publicado em Currículo sem Fronteiras com autorização dos autores. 